\title{
Neurobiological correlates of successful deep brain stimulation in a mouse model of high trait affect
}

\author{
Claudia Schmuckermair ${ }^{1}$, Stefano Gaburro ${ }^{1,2}$, Anupam Sah', Rainer Landgraf ${ }^{3}$, Simone B Sartori ${ }^{1}$, \\ Nicolas Singewald ${ }^{1 *}$
}

From 18th Scientific Symposium of the Austrian Pharmacological Society (APHAR). Joint meeting with the Croatian, Serbian and Slovenian Pharmacological Societies.

Graz, Austria. 20-21 September 2012

\section{Background}

Recent evidence suggests that high-frequency deep brain stimulation of the nucleus accumbens (NAcb-DBS) may represent a novel therapeutic strategy for individuals suffering from treatment-resistant depression although the underlying mechanism of action remains largely unknown. Using a unique psychopathological mouse model of enhanced depression- and anxiety-like behavior (HAB) we investigated behavioral and neurobiological effects of NAcb-DBS.

\section{Methods}

HAB mice underwent either chronic treatment with different selective serotonin reuptake inhibitors (SSRIs) or stereotactic surgery to implant DBS electrodes into the NAcb. NAcb-DBS was applied for $1 \mathrm{~h}$ daily for seven consecutive days $(130 \mathrm{~Hz}, 100 \mu \mathrm{A}, 60 \mu$ s pulse width) and sham-stimulated animals were used as controls. Anxietyand depression-related behaviors were assessed using established tests with predictive anxiolytic or antidepressant validity. Furthermore, the effects of NAcb-DBS on challenge-induced immediate early gene expression and hippocampal neurogenesis were investigated.

\section{Results}

Chronic SSRI treatment did not alter the enhanced depression-like behavior of HAB mice, while repeated, but not single, NAcb-DBS induced robust antidepressant and anxiolytic responses. Interestingly, NAcb-DBS did

\footnotetext{
* Correspondence: nicolas.singewald@uibk.ac.at

'Department of Pharmacology and Toxicology, Leopold-Franzens-University of Innsbruck, 6020 Innsbruck, Austria

Full list of author information is available at the end of the article
}

not affect behavior in normal depression/anxiety animals (NAB), suggesting a preferential effect of NAcb-DBS on pathophysiologically deranged systems. Antidepressantlike effects of NAcb-DBS were associated with normalization of challenge-induced dentate gyrus hypoactivity and modulation of neuronal activity in various brain regions implicated in stress and depression. Furthermore, NAcb-DBS enhanced the blunted hippocampal neurogenesis in HABs.

\section{Conclusions}

Taken together we show that the normalization of pathophysiologically enhanced depression-like behavior by repeated NAcb-DBS was associated with normalization of aberrant brain activity and rescue of impaired adult neurogenesis, indicating that DBS affects gene expression as well as neuronal plasticity in a defined, mood-associated network. Finally, it is suggested that SSRI-insensitive HAB mice represent a clinically relevant model for elucidating the neurobiological correlates underlying the observed behavioral effects of NAcb-DBS.

\section{Acknowledgements \\ Supported by the Hope for Depression Research Foundation (HDRF/ISAN) and the Austrian Science Fund FWF DK SPIN (W1206).}

\section{Author details \\ ${ }^{1}$ Department of Pharmacology and Toxicology, Leopold-Franzens-University of Innsbruck, 6020 Innsbruck, Austria. ²Department of Physiology, Westfälische Wilhelms-University Münster, 48149 Münster, Germany. ${ }^{3}$ Max Planck Institute of Psychiatry, 80804 Munich, Germany.}

Published: 17 September 2012 
doi:10.1186/2050-6511-13-S1-A44

Cite this article as: Schmuckermair et al:: Neurobiological correlates of successful deep brain stimulation in a mouse model of high trait affect. BMC Pharmacology and Toxicology 2012 13(Suppl 1):A44.

Submit your next manuscript to BioMed Central and take full advantage of:

- Convenient online submission

- Thorough peer review

- No space constraints or color figure charges

- Immediate publication on acceptance

- Inclusion in PubMed, CAS, Scopus and Google Scholar

- Research which is freely available for redistribution

Submit your manuscript at www.biomedcentral.com/submit 